\title{
Growth And Corporate Identity: The Case Of Ocean Spray
}

Caroline Boivin, University of Sherbrooke, Canada

Joanne Roch, University of Sherbrooke, Canada

Francine Rodier, University of Sherbrooke, Canada

\begin{abstract}
To explore the assumption that a firm's strategic initiatives must fit with its corporate identity in order to ensure their success, we conduct an in-depth case study of Ocean Spray's ventures in new products.
\end{abstract}

Keywords: growth, corporate identity, case study

\section{INTRODUCTION}

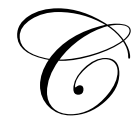

orporate identity describes what is central, distinctive, and enduring about an organization. It thus refers to organizational characteristics that remain relatively stable over time (Albert and Whetten, 1985). Identity is thus the unique character of an organization that develops as a result of its history and experiences (Dutton and Dukerich, 1991). Zook and Allen (2001) argue that, in order to be successful, growth initiatives undertaken by a firm must be related to their core business. Since the core business is an integral part of a firm's identity, it may be assumed that there needs to be some fit between its identity and its growth strategies to ensure their success.

To explore this assumption, we conduct an in-depth case study of Ocean Spray's growth strategies. Ocean Spray, founded almost a century ago, has grown from a one-product company to a multi-product company selling worldwide. It seemed an interesting case to analyze since the company introduced a large number of new products on the market.

In section 2, we present the methodology used in this study. In section 3, the elements of Ocean Spray's identity are identified while in section 4 , the fit between identity and growth strategies is explored. We conclude with a summary in section 5 .

\section{METHODOLOGY}

The methodology used is this study is based on the historical method which is a process of assembling, critically examining and summarizing the records of the past (Gottschalk, 1969; Golder and Tellis, 1993). The primary advantage of historical analysis is that it focuses on information collected at the time the events occurred. The second advantage is that it relies on multiple observers, which strengthens the validity of the results by triangulation.

In order to analyse the diversification strategies of Ocean Spray, we gathered usable information from numerous business press articles as well as press releases and the Internet site of the company. We extracted significant citations in regards of two themes:

- $\quad$ Ocean Spray's corporate identity; and

- $\quad$ Ocean Spray's growth strategies. 
Some degree of uncertainty is inherent in the historical method because the researcher may face evidence that is diverse, complicated and sometimes contradictory (Nevett, 1991). Therefore, we used four criteria in evaluating and accepting information (see Gottschalk, 1969): (i) competence; (ii) objectivity; (iii) reliability; and (iv) corroboration.

The four criteria are met. The competence criterion was satisfied by relying on publications specialized in the food sector as well as business press written at the time Ocean Spray made decisions. The objectivity criterion was satisfied by relying on sources of information provided by third parties who had no vested interest. The reliability criterion was satisfied by using information from respected sources. The corroboration criterion was satisfied by using information from multiple sources.

\section{OCEAN SPRAY'S CORPORATE IDENTITY}

Ocean Spray's corporate identity is made up of different elements which are presented in this section.

\subsection{King Of Cranberry}

Ocean Spray is the world's largest cranberry producer. The cooperative of growers controls approximately three quarters of the world's cranberry supply and has thus created a high barrier to entry on the market (Croft, 11/3/2003; Kosman, 11/8/2003).

\subsection{Health Benefits}

Cranberry is quite unique in terms of the health benefits it provides. On top of containing a large quantity of vitamin $\mathrm{C}$, the fruit is helpful in maintaining a healthy urinary tract (Beverage Industry, 7/2000). Some reports mention that cranberry juice combats bladder infections (Walsh, 11/4/1994).

\subsection{Cooperative Of Growers}

Ocean Spray was founded in 1912 and became a marketing co-operative in 1930 under the initiative of three cranberry growers. The cooperative is now owned by more than 900 cranberry and citrus growers in the US and Canada. (Marketing Week, 8/9/2001; Sidel, 10/8/2004). Its growers own the cooperative. They thus share in the profits and all major decisions must be put to a vote of the growers (Aoki, 9/6/2004).

\subsection{Expertise In New Product Development}

Over the years, Ocean Spray has developed an expertise in new product development. The company conducts focus groups with consumers who provide input on which juice drink flavours or new food products consumers are likely to buy. This is the first step of a highly structured series of stages to test an idea before an actual product is introduced on the market. Between 1989 and 1996, Ocean Spray has introduced 48 new products, seventy percent of which were a success (Stevens, 18/11/1996).

\subsection{Strong Brand Equity}

According to many observers, Ocean Spray is the most durable brand in agriculture (Lord, 9/6/2004). Stu Gallagher, Chief Marketing Officer of the company, mentions that the brand is unlike any other in the juice aisle as the Ocean Spray name and logo evoke clear, distinct images and emotions from consumers - crisp vibrant colors, thirst-quenching taste and down-to-earth sophistication (www.craisins.com). Consumers also link the Ocean Spray name with products they can trust (Masters, 7/1999). 


\subsection{Core Segment: Woman Of The Household}

According to Andrea Foote, editor-in-chief of Beverage World in New York, Ocean Spray has traditionally been a grocery-store brand, appealing to the woman of the household (van der Pool, 23/2/2004).

\section{OCEAN SPRAY'S GROWTH STRATEGIES}

In this section, we present Ocean Spray's growth strategies and examine their fit with its corporate identity.

\subsection{Sauce}

The first Ocean Spray's initiative to expand its market for its cranberry crops was the development of a cranberry sauce (www.oceanspray.com). The sauce became a classic to dress up Thanksgiving turkeys. In 1959, cranberry sauce represented 80\% of Ocean Spray's revenues (Stevens, 18/11/1996). This product may be seen as one step to establish the corporate identity of the company and is compatible with all the elements mentioned in the previous section.

\subsection{Beverages}

The creation of cranberry juice made Ocean Spray's business year-round (Pereira, 9/11/1995). Over the years, Ocean Spray developed many variants and also ventured to other fruits (Aoki, 9/6/2004).

\subsubsection{Cranberry-based juice drinks}

Ocean Spray's flagship product is obviously its cranberry juice drink introduced at the end of the 1950s. In the 1960s, Ocean Spray started blending cranberry juice with other fruit juices starting with a cranberry-apple blend it called Cran.Apple and launched later on a range of pure fruit juices all with cranberry as the dominant flavour (Amanor-Boadu et al.; Grocer, 24/7/1999). Ocean Spray also developed low-calorie juice drinks including the Cranberry Classic Light juice drink (Grocer, 1/3/2003). In a move building on cranberry's health benefits, Ocean Spray released in 2000 its Cranberry Juice Cocktail Plus, a cranberry juice with added calcium (Beverage Industry, 7/2000). In 2001, Ocean Spray launched a line of white cranberry juice drinks which have a smoother and milder taste than red cranberries (Marketing Week, 8/9/2001) as well as a new kids' drink named Crantastics Cocktails (Marketing Magazine, 3/12/2001).

\subsubsection{Non-cranberry juice drinks}

In 1976, Ocean Spray expanded its membership to include some Florida grapefruit growers. In the following years, the cooperative introduced new products including Ocean Spray Grapefruit Juice and Ocean Spray Pink Grapefruit Juice Cocktail and Ocean Spray Ruby Red Grapefruit Juice Drink as well as some blends (www.oceanspray.com). Ocean Spray applied the same product development process to grapefruits as the one used for cranberry-based products (Stevens, 18/11/1996).

\subsubsection{Other beverages}

Ocean Spray also developed types of beverages including a 4-flavour line of Wild Cider beverages targeted at 18- to 22-year-olds launched in 1996 (Khermouch, 15/1/1996) and Juice Spritzers, a line of single-serve carbonated juices launched in 2002 (www.oceanspray.com). The overall game plan is to take on a more mainstream positioning and attract younger people to the brand, while pushing the message about the $40 \%$ fruit juice content (Grocer, 5/5/2001). 


\subsection{Craisins}

Ocean Spray used its product innovation expertise to develop Craisins Sweetened Dried Cranberries which were introduced in 1995. This product quickly became a hit and is found in hundreds of supermarket and bakery products around the globe (www.oceanspray.com). In 2004, Craisins' annual sales had grown to $\$ 100$ million. Promotion efforts continue to target mothers and position Craisins as a smart alternative to chips and candy (van der Pool, 26/1/2004).

\subsection{Ingredient}

Ocean Spray is partnering with other firms to include cranberries in their products through licensing agreements. According to one of the cooperative's officials, licensing gives Ocean Spray the opportunity to leverage its brand into other areas they feel are a good fit with the brand position. To support these partnerships, the Ocean Spray Ingredient Technology Group services the food industry and commercial clients with frozen cranberries, sweetened dried cranberries, flavoured fruit pieces and other fruit ingredients for use in a variety of products (www.oceanspray.com).

\section{SUMMARY: FIT BETWEEN OCEAN SPRAY'S GROWTH STRATEGIES AND ITS IDENTITY}

Table 1 summarizes the link between the various growth initiatives undertaken by Ocean Spray and the elements of the corporate identity of the firm.

Table 1: Link between Ocean Spray's growth initiatives and its corporate identity

\begin{tabular}{|c|c|c|c|c|c|c|}
\hline & Cranberry & $\begin{array}{c}\text { Health } \\
\text { benefits }\end{array}$ & Coop & $\begin{array}{c}\text { Product } \\
\text { development }\end{array}$ & Brand & $\begin{array}{c}\text { Woman of } \\
\text { the household }\end{array}$ \\
\hline Sauce & + & + & + & + & + & + \\
\hline $\begin{array}{c}\text { Cranberry- } \\
\text { based juices }\end{array}$ & + & ++ & + & + & + & + \\
\hline $\begin{array}{c}\text { Non-cranberry- } \\
\text { based juices }\end{array}$ & - & + & + & + & +- & +- \\
\hline Other beverages & +- & +- & + & + & +- & - \\
\hline Craisins & + & + & + & + & + & +- \\
\hline Ingredient & + & + & + & + & + & +- \\
\hline
\end{tabular}

\section{AUTHOR INFORMATION}

Joanne Roch, associate professor in the Department of Management in the Faculty of Business at the University of Sherbrooke, is also vice dean of research of the Faculty of Business. From 1986 to 2001, she worked as an organizational development consultant and strategic management consultant for a variety of Canadian consulting firms and financial companies. In 2003, she completed a doctorate in business, with a focus on strategy, at HECMontreal. Her research interests deal with strategic management, strategic alliances, and challenges related to integration and knowledge transfer.

Caroline Boivin, associate professor in the Department of Marketing at the University of Sherbrooke, is also a research associate with the Bombardier Chair of Brand Management in the Faculty of Business at the University of Sherbrooke. She holds a PhD in business from HEC-Montreal. She specializes in applied industrial organization, technology management, and brand management, and has a particular research interest in strategic alliances between firms in the high-tech and food sectors as well as in brand alliances.

Francine Rodier, doctorate student in the Department of Marketing at the University of Sherbrooke, is also a research professional with the Bombardier Chair of Brand Management in the Faculty of Business at the University of Sherbrooke. She holds a Master's degree in marketing from Sherbrooke and a Bachelor's degree in marketing 
from HEC-Montreal. Francine Rodier has developed an expertise in the agri-food sector. Her research interests focus on marketing strategies linked to branding of agricultural and food products.

\section{REFERENCES}

1. Albert, S. and D. Whetten (2003). Organizational Identity In B.M. Straw \& L.L. Cummins (eds.) Research in Organizational Behavior, JAI Press, 263-295.

2. Amanor-Boadu, Vincent, Michael Boland and David Barton (?), Ocean Spray Cranberries at the Crossroads, Arthur Capper Cooperative Center Case Study Series No.03-01, Department of Agricultural Economics, Kansas State University, 23 pages.

3. Aoki, Naomi (2004) Ocean Spray Cranberry Growers Remains Independent from Pepsi, Knight Ridder Tribune Business News, June 9, p.1.

4. Beverage Industry (2000), State of the industry - Juice: A juice for all seasons, Beverage Industry, July, vol.91, no.7, p.34,36.

5. $\quad$ Croft, Tara (2003), Ocean Spray revamps board, The Daily Deal, March 11, p.x.

6. Dutton, J.E., and J.M. Dukerich, (1991). Keeping an Eye on the Mirror: Image and Identity in Organizational Adaptation. Academy of Management Journal. 34(3), 517.

7. Golder, P.N. and G.J. Tellis (1993), Pioneer Advantage: Marketing Logic or Marketing Legend?, Journal of Marketing Research, 30(2), 158-171

8. $\quad$ Gottschalk, L.R. (1969), Understanding History: A Primer of Historical Method, Knopf.

9. $\quad$ Grocer (1999), Purely logical step for Ocean Spray, Grocer, July 24, vol.222, no.7415, p.48.

10. Grocer (2001), Dilutables makeover, Grocer, May 5, vol.224, no.7502, p.68.

11. Grocer (2003), Ocean Spray's variety for committed consumers, Grocer, March 1, vol.226, no.7593, p.51.

12. Nevett, T. (1991), Historical Investigation and the Practice of Marketing, Journal of Marketing, 55, 13-23

13. Khermouch, Gerry (1996), Ocean Spray Tries Cider with 'Tude, Brandweek, January 15, vol.37, no.3, p.3.

14. Kosman, Josh (2003), Ocean Spray: Crave the sale?, The Deal.com, August 11, p.1.

15. Lord, Robin (2004), Ocean Spray Decides Not to Partner with Pepsi, Knight Ridder Tribune Business News, June 9, p.1.

16. Marketing Magazine (2001), Crantastics wave catches kids, Marketing Magazine, December 3, vol.106, no.48, p.1.

17. Marketing Week (2001), Ocean Spray trials white berry juice, Marketing Week, September 8, p.8.

18. Masters, Greg (1999), All Juiced Up, Discount Merchandiser, vol.39, no.7, pp.107-110.

19. Ocean Spray's web site: www.oceanspray.com

20. Pereira, Joseph (1995), Unknown fruit takes on unfamiliar markets, The Wall Street Journal, November 9, p.B1.

21. Sidel, Robin (2004), Seeing Red: Ocean Spray Is Hamstrung By Cranberry Growers' Feuds; Co-op Loses Ground to Giants In Single-Serving Market; Farmers Snub Pepsi Pact; Randy Jonjak's E-Mail Blitz, Wall Street Journal, August 10, p.A1.

22. $\quad$ Stevens, Tim (1996), Making waves, Industry Week, November 18, vol.245, no.21, pp.28-33.

23. Van der Pool, Lisa (2004), OS Seeds Craisins' Growth, Brandweek, January 26, vol.45, no.4, p.15.

24. Van der Pool, Lisa (2004), Ocean Spray Rolls Effort That Rocks, Brandweek, February 23, vol. 45, no.8, p.6.

25. Walsh, Matt (1994), Juice wars, Forbes, April 11, vol.153, no.8, pp.58-59.

26. Zook, C. and J. Allen (2001), Profit from the Core: Growth Strategies in an Era of Turbulence, Harvard Business School Press. 


\section{NOTES}

